\title{
DLACZEGO WENUS SPRZYJAŁA \\ PORTUGALCZYKOM? \\ O ROLI RZYMSKIEGO ANTYKU \\ W TRAKTACIE KWIATY HISZPANII, \\ WSPANIAŁOŚCI PORTUGALII (1631) \\ ANTÓNIA DE SOUSA DE MACEDO
}

Anna Działak-Szubińska*

\begin{abstract}
The article brings forth an analysis of the antiquity-evoking themes displayed by the seventeenth-century treatise Flores de España, excelencias de Portugal (1631) by António de Sousa de Macedo (1608-1682). The author tellingly acknowledges the Roman heritage of the Iberian Peninsula, a fact that becomes intimately entwined with the patriotic narration of the origins of the nation. Antiquity is seen as the source of national pride and a handy weapon to protect anything Portuguese when the Iberian Union (1581-1640), which brought together Portugal and Spain, was in decline.
\end{abstract}

Keywords: António de Sousa de Macedo, Flores de España, excelencias de Portugal, Iberian Union, Antiquity, Roman heritage.

Słowa kluczowe: António de Sousa de Macedo, Flores de España, excelencias de Portugal, unia iberyjska, antyk, rzymskie dziedzictwo.

\footnotetext{
* Uniwersytet Warszawski, Wydział Neofilologii, Instytut Studiów Iberyjskich i Iberoamerykańskich, ul. Oboźna 8, 00-332 Warszawa, anna.dzialak@hotmail.com.
} 
Traktat Kwiaty Hiszpanii, wspaniałości Portugalii (Flores de España, excelencias de Portugal) Antónia de Sousa de Macedo (1606-1682), portugalskiego pisarza i dyplomaty, został po raz pierwszy wydany drukiem w 1631 roku w Lizbonie. Spośród wielu funkcjonalnych aspektów traktatu na szczególną uwagę zasługują obecne w nim odwołania do tradycji antycznej. To właśnie one będą przedmiotem analizy w artykule. Odniesienia te, jak wykażę, nie tylko stanowią erudycyjny ozdobnik, lecz także wpisują się w szerszą estetykę europejską. Są także ściśle powiązane z ówczesną sytuacją polityczną Portugalii.

Utwór został wydany w schyłkowym okresie rządów dynastii habsburskiej w Portugalii. Habsburgowie zasiedli na portugalskim tronie w 1581 roku po wygaśnięciu rodzimej dynastii Avis. Unia personalna z czasem stała się dla Portugalczyków politycznie i gospodarczo niewygodna, a Portugalia została wciągnięta wbrew swoim interesom w konflikty zbrojne (np. konflikt w Niderlandach). W następstwie działań grupy spiskowców związek Portugalii z Hiszpanią został zerwany w 1640 roku, a królem Portugalii ogłoszono Jana IV, który dał początek dynastii Bragança (szerzej np. Saraiva, 2000: 205-230; Działak-Szubińska, 2015: 2-3).

Stosunkowo obszerna (252 karty, 24 rozdziały) praca Kwiaty Hiszpanii, wspaniałości Portugalii poświęcona jest szeroko pojętej pochwale Portugalii, przedstawionej jako kluczowy region Półwyspu Iberyjskiego. Duża jest także różnorodność tematyczna pracy. António de Sousa de Macedo pisze o historii, polityce, kulturze, geografii, przyprawiając wszystko szczyptą narodowej megalomanii.

Odwołania do tradycji antycznej widać w dziele Antóniego de Sousa de Macedo na wielu poziomach. Są one związane z profilem wykształcenia odebranego przez autora, który w wieku szesnastu lat rozpoczął studia na Uniwersytecie w Coimbrze - najstarszej portugalskiej uczelni (szczegółowe informacje o biografii autora por. da Costa de Sousa de Macedo 2003: XIII)1․ Obecność sta-

1 Erudycja pisarza zasługuje na szczególne uznanie ze względu na to, że w momencie powstania pracy miał on zaledwie dwadzieścia dwa lata. Autor nie zapomina o tym wspomnieć między innymi 
rożytnych nawiązań na poziomie konceptów oraz inspiracji jest także związana z rolą antyku w nowożytnej (i nie tylko) Europie. Na jego szczególne miejsce w świecie literacko-intelektualnym zwracali uwagę cenieni polscy badacze, tacy jak Juliusz Domański (2009), Tadeusz Sinko (1988) czy Tadeusz Bieńkowski (1976, 1990: 30-39).

W przypadku omawianego tu traktatu klasyczne są: układ pracy, zaplecze retoryczne i sposób argumentacji, a także odniesienia literacko-kulturowo-historyczne, w tym zarówno odsyłacze bibliograficzne, jak i topiczne imaginarium. Klasyczne jest zatem również postrzeganie Półwyspu Iberyjskiego. Hiszpania to dla Antóniego de Sousa de Macedo wszystkie ziemie iberyjskie.

Zostawiając z boku kwestie techniczne, w artykule skupię się przede wszystkim na tym, jak de Sousa de Macedo operuje tematyką rzymską. Kategorie, które chciałabym wyróżnić w omawianym tu traktacie, są w tych ramach następujące: argumentacja z powołaniem się na autorów rzymskich, paralele szkicowane między Portugalczykami i Rzymianami, przywołanie rzymskich autorów wypowiadających się o mieszkańcach Portugalii, Portugalczycy przedstawieni w swoich kontaktach z Rzymianami oraz elementy rzymskiego dziedzictwa przedstawione w kontekście iberyjskim. Jak zobaczymy, wykorzystanie tych kategorii odbywa się na kilku płaszczyznach. Jednak w wielu przypadkach służy uwzniośleniu Portugalczyków.

Nadmieńmy także, że zastosowanie wątków antycznych jest zbieżne z obserwacjami przytoczonych wcześniej polskich badaczy. Mianowicie, jak zauważyli Bieńkowski (1976: 170-178; 1990: 30-39) i Sinko (1988), antyk jest dla europejskich autorów źródłem przykładów, cytatów, zapożyczeń, motywów, choć w przypadku literatury barokowej stają się one często, jak pisze Bieńkowski, „ornamentyką stylistyczną" (Bieńkowski, 1990:

w prologu skierowanym do króla. Pisze w nim o „kwiatach Hiszpanii i kwiecie swych dwudziestu dwóch lat” (de Sousa de Macedo, 1631). Na młody wiek autora zwracają uwagę także cenzorzy (ibidem). 
38). Przyjrzymy się zatem, jak z tego instrumentarium korzysta António de Sousa de Macedo w traktacie Kwiaty Hiszpanii, wspaniałości Portugalii.

Powoływanie się na autorytet innych pisarzy stanowi jedno z ulubionych narzędzi argumentacyjnych Antónia de Sousa de Macedo. W niektórych przypadkach takie dowodzenie jest tożsame $\mathrm{z}$ argumentem $\mathrm{z}$ autorytetu. Odniesienia do poważanych twórców wynikają bowiem, jak już wspomniałam, z zaplecza intelektualnego autora. De Sousa de Macedo chętnie czerpie ze skarbnicy antycznych mądrości. Odnosi się do Cycerona, Horacego, Owidiusza, Pliniusza Młodszego, Platona, Plutarcha, Strabona, Tacyta, Wergiliusza. Niekiedy cytuje ich bezpośrednio, opatrując przypisem bibliograficznym, czasami nawiązuje jedynie do ich myśli. Cytowane fragmenty dzieł twórców rzymskich czy greckich nie zawsze są związane z Portugalią. Autor po prostu przytacza klasyczne wykładnie, na przykład odwołuje się do poglądów, uwag czy sądów Cycerona o mowie ojczystej (de Sousa de Macedo, 1631: 234v)², Horacego o bogactwie [19v], Seneki o obżarstwie [229v] czy Tacyta o obowiązkach rządzących [1v]. Odwołania te są erudycyjne i nie można wykluczyć, że zostały zaczerpnięte z innych prac $^{3}$. Niemniej, przydają one dziełu wiarygodności, tworzą wrażenie rzetelności pracy badawczej, a wygłoszonym sądom przypisują wartość niepodważalnej prawdy. Co więcej, uwagi te są bezpośrednio związane z tematami poruszanymi w pracy. Stanowią zatem wsparcie argumentacyjne. Równocześnie trzeba odnotować, że taką samą wartość mają cytaty pochodzące z dzieł średniowiecznych i nowożytnych.

W traktacie znajdziemy też pozytywne opisy ziemi portugalskiej i jej mieszkańców cytowane pośrednio lub bezpośrednio za autorami klasycznymi - greckimi oraz rzymskimi. I tak na przykład António de Sousa de Macedo cytuje pochwały rzeki Tag

2 Wszystkie cytaty z dzieła de Sousa de Macedo pochodzą z tego samego wydania z $1631 \mathrm{r}$. i są lokalizowane cyframi w nawiasach kwadratowych.

3 O ekscerpowaniu, florilegiach, sentencjach i erudycji humanistycznej por. Pawlak, 2012. 
autorstwa Marcjalisa, Syliusza Italikusa czy Klaudiana [Klaudiusza] [11r]. Wspomniane są także między innymi bogactwa naturalne, na przykład złotonośne rzeki, o których pisał Katullus [20r]. Te cytaty i odnośniki wzmacniają w oczywisty sposób wartość Portugalii, ale - co istotne - te nawiązania tworzą także wrażenie ciągłości historycznej między antykiem a epoką, w której żył i tworzył autor traktatu.

Tak jak wspomniałam, antyk jest dla Antónia de Sousa de Macedo źródłem porównań. Przykładowo kastylijski król Alfons VI, ojciec matki pierwszego króla Portugalii, zostaje przyrównany do Konstantyna Wielkiego [38v], zaś zewnętrzne walory, swoisty urok władcy z drugiej dynastii królów portugalskich, panującego w latach 1367-1382, Ferdynanda I Pięknego, zostają zestawione z urodą Eneasza [44v]. Uczucie, które połączyło Ferdynanda Pięknego z Eleonorą Teles de Menezes zostało przedstawione na tle wielu mitologicznych opowieści. António de Sousa de Macedo przywołuje w tym kontekście, między innymi, historię Narcyza i Echo, Meduzy i Neptuna, Dafne i Apolla, Jupitera i Europy, Pigmaliona. Opowieści te, podobnie jak dzieje miłości Ferdynanda i Elenory, nie mają „szczęśliwego zakończenia” [170v i kolejne]. Tak więc, mając na względzie dokonania Rzymian i nośność dzieł rzymskiego antyku oraz grecko-rzymskiej mitologii, de Sousa de Macedo niejednokrotnie rysuje paralelę między Portugalczykami a związanymi ze starożytnym Rzymem postaciami historycznymi i mitologicznymi.

W podobny sposób zostały także skomponowane bardziej ogólne narracje. Opis cnót portugalskich władców jest zbudowany na odniesieniach do postaci ze starożytności, tak jak w tym fragmencie:

Portugalczycy przyzwyczaili się, że ich królowie byli [Numami] Pompiliuszami w kwestiach religijnych, Likurgami w tych związanych z rządzeniem, Anaksagorasami w tym, co tyczy stałości charakteru, Trajanami w dobroci, Radamantysami w srogości [...], Juliuszami Cezarami w tym, co dotyczy odwagi [...], Judami Machabeuszami w sile moralnej, Septymiuszami Sewerami w ostrożności, Oktawianami w szczęściu [...] [232v-233r]. 
Cechy oraz dokonania starożytnych bohaterów stają się tu elementem porównawczym, wykorzystanym do zbiorowej charakterystyki portugalskich monarchów. Wyselekcjonowane pozytywne cechy utożsamione $\mathrm{z}$ konkretnymi postaciami z historii i mitologii służą do uwznioślenia portugalskich władców. Podobnie wszystkie Portugalki zostają porównane do Lukrecji, żony Lucjusza Tarkwiniusza Kollatyna, wzoru cnót małżeńskich i skromności [130r].

Czasami analogie tworzone są także w sposób pośredni. Przykładowo de Sousa de Macedo przytacza sformułowaną przez Wergiliusza pochwałę dzielnych niewiast, by następnie przejść do opowieści o sławnych i dzielnych Portugalkach [199r i kolejne]. Jak zaznacza Bieńkowski (1990: 38), taki zabieg jest zresztą właściwy dla literatury barokowej, w której postaci związane $\mathrm{z}$ antykiem zyskują znaczenie symboliczne, są ucieleśnieniem konkretnych wad i zalet, a także zawodów. Faktycznie, w przypadku wymienionych powyżej postaci z dziejów Rzymu, skojarzenia $z$ konkretnymi cnotami i umiejętnościami są oczywiste. Niektóre z nich funkcjonują także w kontekście topicznym, jak na przykład Juda Machabeusz, jeden z neufpreux - dziewięciu dzielnych mężów, wcielonych zalet moralnych powiązanych z etosem rycerskim ${ }^{4}$.

Podobny mechanizm porównawczy został także zastosowany przy opisie żyznej, pięknej, zielonej Portugalii, którą zestawiono z Polami Elizejskimi [8v-9r], przy czym to konkretne porównanie zostało również oparte na przesłankach etymologicznych. Mianowicie od Pól Elizejskich - Campos Elysios de Sousa de Macedo wywodzi słowo Luzytania (Lusitania) - określenie części jednej z prowincji iberyjskich pod panowaniem rzymskim i termin służący do określania Portugalii jeszcze w epoce nowożytnej. Autor traktatu buduje pseudoetymologiczny argument poprzez skojarzenie fonetyczne - Lusitania / Lysitania / Campos Elysios. Zestawienie Portugalii z Polami Elizejskimi jest także oparte na

4 Neuf preux to Hektor, Juliusz Cezar, Aleksander Wielki, Jozue, król Dawid, Juda Machabeusz, król Artur, Karol Wielki, Gotfryd de Bouillon. Por. na przykład Huizinga, 1961: 94; Curtius, 1977: 381. 
przesłankach mitologicznych, a konkretnie zaczerpnięte z Eneidy i Odysei. Otóż de Sousa de Macedo twierdzi, że portugalska rzeka Limia to Lete, do której, według Wergiliusza, przybył Eneasz [9r]. Przywołuje także opowieści o Odyseuszu. Bohater ten ponoć dotarł „na same krańce Hiszpanii”, gdzie miały się znajdować Pola Elizejskie $[8 \mathrm{v}]^{5}$. Autor traktatu utożsamia więc Portugalię z tym właśnie mitycznym miejscem i tym samym kreuje niezwykle pozytywny obraz Portugalii.

Widzimy zatem wyraźnie, że de Sousa de Macedo buduje siatkę pozytywnych, topicznych skojarzeń, która służy uwydatnieniu zalet Portugalii, podkreśleniu roli rządzących, którzy stali na czele organizacji wspólnotowej i byli z nią utożsamieni, a także ukazaniu cnót zwykłych mieszkańców. Autor wpisuje się tym samym w topikę pochwały szeroko omówioną przez Curtiusa (1997). Taki zabieg może służyć uwypukleniu pewnych wątków w dziejach kraju, uniwersalizacji, ale również ma na celu zaakcentowanie dokonań portugalskich bohaterów i, w pewnym stopniu, służy przeniesieniu dziejów Portugalii w wymiar mityczny ${ }^{6}$. Bieńkowski zaznacza, że jedna z przyczyn obecności antyku w literaturze to „głęboka nośność ideowa i moralna wielu epizodów $z$ historii Grecji i Rzymu oraz wielu wypowiedzi filozofów, władców i bohaterów antycznych" (1990: 37). I choć uwagi badacza dotyczą XVI-wiecznej literatury polskiej, śmiało można je odnieść do omawianego tu portugalskiego traktatu.

Nobilitacja Portugalii budowana na kontekście rzymskim bywa także pozbawiona topiczno-erudycyjnej otoczki. Przykładowo de Sousa de Macedo pisze, że choć Imperium Rzymskie było ogromne i potężne, to Imperium Portugalskie obejmuje więcej kontynentów. Rzym jest tu tylko punktem odniesienia do

5 Zgodnie z tradycją Lizbona została założona przez Odyseusza. Sugeruje się, że nazwa miasta używana w czasach rzymskich (Olisipo) pochodzi właśnie od Ulissesa. Opowieść tę znajdziemy chociażby w ośmiotomowej pracy o dziejach Portugalii - Monarchia Lusitana (1597-1729).

6 O mitycznym wymiarze dziejów Portugalii w pracy Luísa Vaz de Camõesa por. Kalewska, 1999. Portugalczycy mają tendencję do sakralizacji i mityfikacji dziejów własnych. 
wyrażenia uznania dla wielkości Portugalii i jej rozległych zamorskich terytoriów [28r].

W Kwiatach Hiszpanii, wspaniałościach Portugalii pojawia się także pewna liczba opisów dotyczących kontaktów Rzymian i Luzytanów - plemienia szczególnie ważnego dla tożsamościowej narracji Portugalczyków. Lud ten zamieszkiwał częściowo na obszarze dzisiejszej Portugalii, co tłumaczy proces autoidentyfikacji Portugalczyków z Luzytanami.

Jak już wspomniałam, nawiązując do rzymskiej terminologii, wielu autorów określało Portugalię mianem Luzytania (Lusitania). Należy do nich między innymi André de Resende (De antiquitatibus Lusitaniae, 1593), António Vasconcelos (Anacephalaeoses id est, summa capita actorum regum Lusitaniae, 1621)7 a także właśnie António de Sousa de Macedo (Genealogia Regum Lusitaniae, 1643; Lusitania liberata ab injusto Castellanorum dominio, 1645). Warto pamiętać, że narodowa epopeja portugalska autorstwa Luísa Vaz de Camõesa nosi także tytuł Os Lusíadas - Luzytanie.

Takie terminologiczne powiązanie Luzytanii z Portugalią oraz utożsamienie Luzytanów z Portugalczykami możemy zauważyć w omawianym tu traktacie. António de Sousa de Macedo dowodzi, że choć mieszkańcy Portugalii zostali podporządkowani przez Rzymian i uznali ich zwierzchnictwo, odmawiali stawania $\mathrm{z}$ bronią $\mathrm{w}$ ręku przeciw swym zbuntowanym pobratymcom z terenów Półwyspu Iberyjskiego [137r]. Zdaniem portugalskiego autora, wierność i uczciwość Luzytanów zapewniła im także miejsce u boku Juliusza Cezara i to spośród nich rekrutowali się członkowie jego straży [149v-150r]. Autor szeroko opowiada także o szacunku, jakim cieszyli się Portugalczycy u Rzymian [243r]. W tym kontekście przytacza także opowieść Marka Porcjusza Katona o dzielnej mieszkance Portugalii, która dokonała aktu

7 Dzieło Antónia Vasconcelosa zawiera także spersonifikowane przedstawienie Luzytanii - pięknej, młodej kobiety w rzymskiej zbroi, z hełmem na głowie, włócznią i krzyżem odpowiednio w prawej i lewej dłoni. Łączy ona w sobie to, co minione i to, co współczesne autorowi, a więc rzymskie uzbrojenie z portugalską heraldyką i krzyżem. Wskazuje to na wizualną nośność rzymskiego antyku. 
niezwykłej odwagi, broniąc swej ojczyzny przed rzymskimi najeźdźcami [126v-127r]. Wreszcie wspomina także historię sławnego dowódcy Luzytanów - Wiriatusa [156v, 159v]. Zauważmy, że António de Sousa de Macedo używa określeń Luzytanie i Portugalczycy wymiennie. Ten ahistoryczny zabieg jest spójny z tożsamościową narracją Portugalczyków. Pozwala też rozszerzyć historię własną Portugalii o wątki poprzedzające faktyczne narodziny niezależnej Portugalii w pierwszej połowie XII wieku.

Nobilitacji Portugalii służy również przypisanie portugalskiego pochodzenia wielu wybitnym Rzymianom. Należą do nich Seneka, cesarz Wespazjan czy Publio Daciano - rzymski prefekt z czasów Dioklecjana [58v-59r]. Według Antóniego de Sousa de Macedo Portugalczykami są także Orozjusz i św. Augustyn [67v i kolejne]. Na tych przykładach widać, jak nowożytny autor manipuluje przedstawianymi informacjami. Po pierwsze, podejście Antóniego de Sousa de Macedo jest anachroniczne. Po drugie, żaden z powyżej wymienionych przedstawicieli rzymskich elit nie pochodził z terenów dzisiejszej Portugalii, choć Seneka czy Orozjusz faktycznie byli związani z ziemiami Półwyspu Iberyjskiego.

Jak widać, de Sousa de Macedo traktuje dawne prowincje rzymskie obejmujące swoim zasięgiem współczesną mu Portugalię jako „poprzedniczki” nowożytnego portugalskiego imperium, a Portugalczykami są dla niego nie tylko rdzenni mieszkańcy tych ziem, ale i rzymskie elity zamieszkałe na Półwyspie Iberyjskim. I choć dla de Sousa de Macedo Seneka i św. Augustyn są Portugalczykami, autor nie waha się przytoczyć opowieści o walce Luzytanów z Rzymianami. Kulminacyjny moment stanowi, z jednej strony, opowieść o Wiriatusie, który bronił terytorium późniejszej Luzytanii przed Rzymianami [156v, 159v], z drugiej zaś stwierdzenie, że Rzymianie to tak naprawdę Portugalczycy, bo założyciele Rzymu - według de Sousy de Macedo Italus, Roma - córka Atlasa i ich portugalscy towarzysze - pochodzili z terytorium Półwyspu Iberyjskiego [159r].

Trzeba tu zresztą zaznaczyć, że takie wzbogacanie historii własnej, w tym włączanie do niej wątków rzymskich, nie jest niczym wyjątkowym w kontekście europejskiej historiografii (por. na przykład Kłoskowska, 2005: 67). Przykładowo do rzymskich 
korzeni odwoływał się w średniowieczu Mistrz Wincenty Kadłubek (ok. 1160-1223). Kronikarz kazał naszym przodkom walczyć z Rzymianami, a także zlatynizował imię przywódcy Polan - Kraka (Grakchus) (1996: ks. I, 3-4), co w oczywisty sposób nobilitowało piastowski rodowód. Jak pisze Henryk Samsonowicz, „[w]iedza o antyku stanowiła rusztowanie, na którym umieszczano znane i domniemane wydarzenia z przeszłości. Dobór ich mógł być przypadkowy, ale dotyczył zawsze kwestii zasadniczej dla wspólnej świadomości grupy ludzkiej; jej początku i jej odrębności" (Samsonowicz, 1997: 31). Z kolei zdaniem Antoniny Kłoskowskiej, budulcem tożsamości narodowej jest poza ziemią i krwią także czas. Jak pisze, mity opowiadające o początkach społeczności są zazwyczaj osadzone w bardzo odległej, często wyobrażonej przeszłości. Argument „z dawności”, odwołanie do początków wspólnoty dodatkowo legitymizuje prawo do suwerenności i danego terytorium, potwierdza także prymat danej nacji (Kłoskowska, 2005: 81). António de Sousa de Macedo wpisuje się zatem w taki sposób pisania dziejów własnych.

W przypadku Kwiatów Hiszpanii, wspaniałości Portugalii wzbogacenie historii własnej o mitologiczno-historyczne wątki rzymskie wykracza jednak poza przestrzeń symboliczną. W traktacie ważne miejsce zajmuje przecież szeroko pojęte rzymskie dziedzictwo. I tak António de Sousa de Macedo zwraca uwagę na obecne w przestrzeni portugalskiej ślady rzymskiej kultury. W jego ujęciu należą do nich religia chrześcijańska czy siatka urbanistyczna. Zgodnie z wykładnią Antóniego de Sousa de Macedo, to właśnie w Portugalii w czasach rzymskich pojawili się pierwsi chrześcijanie w Europie [98r]. De Sousa de Macedo pisze, że Braga jest jednym z najstarszych ośrodków kultu powiązanych z chrześcijaństwem [98v-118v]. Przy czym to miasto, dzisiaj duchowa stolica Portugalii i siedziba prymasa, faktycznie jest stolicą najstarszej iberyjskiej diecezji.

Jak mówi autor traktatu, to także Rzymianie rozwinęli wiele ważnych ośrodków miejskich w Portugalii: Lizbonę, Évorę, Beję, Santarém, Chaves czy wspomnianą już Bragę [213r]. Wreszcie to także Rzymianie dali początek językowi portugalskiemu, którego pochwale autor poświęca cały oddzielny rozdział. Wymienia 
w nim wiele zalet języka portugalskiego: jego łatwą wymowę, bogactwo stylistyczne i zwięzłość, ale także niezwykłe podobieństwo do łaciny [234v i kolejne, szczególnie 239r-240r]. Portugalczycy są więc spadkobiercami Rzymian także w tym aspekcie. De Sousa de Macedo porusza się zatem płynnie między przeszłością a czasami sobie współczesnymi. Nadmieńmy, że przytaczana przez niego argumentacja nie jest oryginalna - autor czerpie z wielu innych prac, chociażby z Duarte Nunesa de Leão, który poświęcił całą księgę językowi portugalskiemu czy z gramatyki języka portugalskiego João de Barrosa.

Tak jak wspomniałam na wstępie, pochwała Portugalii ma szczególne znaczenie w trudnym okresie politycznym, w jakim znalazła się ona w latach trzydziestych XVII wieku. Jednym z narzędzi wykorzystywanych do realizacji politycznych celów - walki o respektowanie przez Habsburgów obietnic politycznych, szerszą autonomię, a z czasem i powrót rodzimej dynastii - była literatura. Portugalski badacz Hernâni Cidade mówi wręcz o istnieniu swoistego nurtu literackiego, który nazywa literaturą autonomistyczną. Literatura ta, jak zaznacza badacz, podkreślała odrębność polityczną, historyczną i kulturową kraju. Jej ważnym elementem była historiografia pełna heroicznych czynów, a także elementów fantastycznych i nadprzyrodzonych (Cidade, 1950). Wśród prac z tego nurtu badacze wymieniają także omawiany tu traktat Kwiaty Hiszpanii, wspaniałości Portugalii (por. Nogueira da Silva, 2001: 350). W tym kontekście, mając na względzie pochwałę Portugalii obecną w traktacie, a także idealizację samych Portugalczyków, należy uznać, że odwoływanie się do rzymskiego dziedzictwa dodatkowo promowało Portugalię i Portugalczyków w Europie. Takie konstruowanie symbolicznej potęgi kraju, dowodzenie jego niezależności, a nawet prymatu na Półwyspie Iberyjskim oraz wyższości nad innymi regionami Hiszpanii było w interesie Portugalczyków. Starożytni Rzymianie byli ważnym ogniwem w tożsamościowej narracji Portugalczyków ze względów prestiżowych.

Reasumując: w traktacie Kwiaty Hiszpanii, wspaniałości Portugalii antyk rzymski zajmuje poczesne miejsce w argumentacyjnym instrumentarium. António de Sousa de Macedo wykorzy- 
stuje zarówno motywy z rzymskich dziejów i mitologii, jak i prace rzymskich autorów, a także rzymskie dziedzictwo na Półwyspie Iberyjskim, by podkreślić rangę swojej ojczyzny. Nadrzędnym celem Antóniego de Sousy de Macedo nie jest przekazanie faktów historycznych, lecz wykorzystanie przeszłości dla literacko-politycznych potrzeb. Stąd wspomniane powyżej jawne manipulacje oraz zmyślenia. Zabiegi Antóniego de Sousa de Macedo służą legitymizacji portugalskiej państwowości, a także nobilitują Portugalię, wzmacniając równocześnie poczucie dumy u jej mieszkańców. Na przykładzie traktatu można zatem zaobserwować zjawisko funkcjonalizacji tradycji antycznej (por. Bieńkowski, 1976: 8).

Odnosząc się zaś do pytania postawionego w tytule artykułu, warto podkreślić, że we wspomnianej już epopei Luzytanie Luísa Vaza de Camõesa bogini Wenus darzy Portugalczyków szczególną sympatią, ponieważ dostrzega ich podobieństwo do Rzymian. To do tej tradycji nawiązuje António de Sousa de Macedo. Autor Kwiatów Hiszpanii, wspaniałości Portugalii w szczególny sposób docenia rzymskie dziedzictwo Półwyspu Iberyjskiego i wpisuje je w patriotyczną narrację o genezie narodu, tj. uznaje Portugalczyków za bezpośrednich spadkobierców Rzymian, tak pod względem politycznym, jak i kulturowo-językowym.

\section{Bibliografia}

Bieńkowski, T. (1976): Antyk w literaturze i kulturze staropolskiej (1450-1750). Główne problemy i kierunki recepcji. Wrocław/Warszawa/Kraków/Gdańsk: Zakład Narodowy im. Ossolińskich - Wydawnictwo Polskiej Akademii Nauk. Bieńkowski, T. (1990): „Antyk”. W: T. Michałowska przy udziale B. Otwinowskiej i E. Sarnowskiej Temeriusz (red.), Stownik literatury staropolskiej (średniowiecze - renesans - barok). Wrocław/Warszawa/Kraków: Zakład Narodowy im. Ossolińskich, 30-39.

Cidade, H. (1950): A literatura autonomista sob os Filipes. Lisboa: Livraria Sá da Costa Editora.

da Costa de Sousa de Macedo, P. (2003): "Prefácio" W: A. de Sousa de Macedo, Flores de España. Excelencias de Portugal. En que brevemente se trata lo mejor de sus historias, y de todas las del mundo desde su principio 
hasta nuestros tiempos, y se descubren muchas cosas nuevas de provecho, y curiosidad. Primera parte. A la magestad del Rey Catholico de las Españas Don Phelipe IIII (facsimile). Lisboa: Livraria Alcalá, I-XXVI.

Curtius, E. R. (1997): Literatura europejska i łacińskie średniowiecze, tłum. A. Borowski. Kraków: Universitas.

Domański, J. (2009): Philologica, Litteraria, Humaniora. Studia i szkice z dziejów recepcji dziedzictwa antycznego. Warszawa: Wydział Polonistyki Uniwersytetu Warszawskiego.

Działak-Szubińska, A. (2015): „'Kwiaty Hiszpanii, wspaniałości Portugalii’ (1631) Antóniego de Sousa de Macedo, czyli jak udowodnić 'siłę' Portugalczyków", Res Rhethorica 4: 1-18.

Huizinga J. (1961): Jesień średniowiecza, tłum. T. Brzostowski. Warszawa: Państwowy Instytut Wydawniczy.

Kalewska, A. (1999): Camões czyli tryumfepiki. Warszawa: Wydawnictwa Uniwersytetu Warszawskiego.

Kłoskowska, A. (2005): Kultury narodowe u korzeni. Warszawa: Wydawnictwo Naukowe PWN.

Mistrz Wincenty [tzw. Kadłubek] (1996): Kronika polska, tłum. B. Kürbis. Wrocław/Warszawa/Kraków: Zakład Narodowy im. Ossolińskich.

Nogueira da Silva, C. (2001): „A identidade Portuguesa”. W: R. Carneiro (ed.), Memória de Portugal. O milénio português. Lisboa: Círculo de Leitores, 350-351.

Pawlak, W. (2012): De eruditione comparanda in humanioribus. Studia z dziejów erudycji humanistycznej w XVII wieku. Lublin: Wydawnictwo KUL.

Samsonowicz, H. (1997): O „historii prawdziwej”: mity, legendy i podania jako źródto historyczne. Gdańsk: Novus Orbis.

Saraiva, J. H. (2000): Krótka historia Portugalii, tłum. E. Łukaszyk. Kraków: Universitas.

Sinko, T. (1988): Antyk w literaturze polskiej: prace komparatystyczne. Warszawa: PWN.

Sousa de Macedo, A. de (1631). Flores de España, excelencias de Portugal, en que brevemente se trata lo mejor de sus historias, y de todas las del mundo desde su principio hasta nuestros tiempos, y se descubren muchas cosas nuevas del provecho, y curiosidad. Primera Parte a la Magestad del Rey Catholico de las Españas Don Philippe IIII nuestro Señor. Por Antonio de Sousa de Macedo su moço Fidalgo, y Cavallero del habito de Christo. Con todas las licencias necessarias. Lisboa: Jorge Rodrigues. 